\author{
Michaela Fučeková \\ Undergraduate student \\ University of Žilina, Faculty of Humanities, Department of English Language and Literature, Žilina, Slovakia \\ fucekova.m@gmail.com

\section{RastislavMetruk} \\ Ph.D., Senior lecturer \\ University of Žilina, Faculty of Humanities, Department of English Language and Literature, Žilina, Slovakia \\ rastislav.metruk@gmail.com
}

\title{
DEVELOPING ENGLISH SKILLS BY MEANS OF MOBILE APPLICATIONS
}

\begin{abstract}
Modern technologies appear to be gaining in popularity, and affect every sphere of human activity, including education. Thus, ICT (Information communication technologies) have become an inseparable part of the learning process. This article examines the possibilities of learning English by means of mobile applications. Three mobile devices have been selected for the purposes of this research, namely the smartphone, tablet, and smartwatch. Altogether 38 Slovak participants completed a questionnaire, which contained questions concerning the types of mobile devices as well as places and frequency of the devices used. Furthermore, identifying which skills (listening, reading, speaking, writing), and what type of mobile applications are used were also the focus of this research. The research findings indicate that it is the smartphone which is used the most. The most probable place of using the mobile applications is the learners' home, and when it comes to the frequency, the acquired data illustrate a diverse range in relation to how often the mobile applications are used for the purposes of learning English. As far as the language skills are concerned, it can be concluded that the learners predominantly focus on listening, followed by reading, writing, and speaking. Exploring the preference for language systems, the research results reveal that the participants concentrate on vocabulary, grammar, and pronunciation respectively. Finally, it was found out that it is the dictionary applications which are used the most. It can be concluded that mobile applications represent a powerful and popular educational tool whichis worth attention of teachers, researchers, and academics worldwide, and further investigation into this matter is necessary, and it will certainly prove useful to both language teachers and students.
\end{abstract}

Keywords: Mobile applications; MALL, EFL learner, Language skills, Language systems.

\section{INTRODUCTION}

The problem statement. Modern technologies are experiencing a surge in popularity all over the world in this day and age. The society, working life, and education are changing at a rapid pace, and education as such also calls for new ways of learning. Modern technologies, which form an inseparable part of our everyday lives, are evolving rapidly. This has led to the widespread use of ICT(Information and communication technologies), which redefine thinking and communication of people [1],in almost all spheres of human activity [2], including education. Therefore, it is necessary to conduct research in this field so as to examine how these technologies can facilitate the learning process and aid EFL (English as a foreign language) learners in developing their language abilities.

MALL (Mobile Assisted Language Learning), which involves using mobile technologies in language learning, is relatively a new term in the field of ICT, and its popularity is also increasing. Scientists have been discussing the emergence of learning through mobile devices recently [3]. Moreover, students seem to be motivated to use mobile technologies for educational purposes in this day and age [4]. This study attempts to cast more light on how Slovak university EFL learners use mobile devices for the purposes of developing their language abilities. 
Analysis of recent studies and publications. The subject of MALL has been discussed on numerous occasions in the past 20 years. Research carried out on MALL can be divided into two periods: before 2007 and after 2007. The year 2007 is marked by Apple's iPhone market entry [5] - a touchscreen smartphone with combined capabilities of a PDA (Personal digital assistant) and a computing technology. This event was perceived as a technological revolution changing the whole "mobile game". MALL research conducted before this techbreaking point had been dealing predominantly with mobile language learning via SMS or email and through PDAs or mobile phones. Newer research, however, primarily focuses on mobile language learning with smartphones and tablets as well as applications in these devices [6].

Vavoula and Sharples [7] claim that mobile learning can be discussed in terms of space and time. Therefore, mobile learning is any learning that occurs on the go, anytime and anywhere with the use of mobile devices. Kukulska-Hulme [8] stated that it is difficult to agree on the exact definition of mobile learning and teaching since there are two possible angles of viewing the word mobile in the context of this term. The first way is linked to mobile technologies themselves, and the second is connected with the association that learners are on the go, hence the term mobile. Later, Kukulska-Hulme [9] attempted to define MALL as "the use of mobile technologies in language learning, especially in situations where device portability offers specific advantages". According to O'Malley et al. [10, p. 6], it is "any kind of learning that takes place when the learner is not in a fixed and predetermined place, or it is learning that happens when the learner takes advantage of learning opportunities offered and provided by mobile technologies".

We agree with the notion that "MALL has the potential of fundamentally disrupting teaching and learning" [6, p. 1], and that mobile devices represent a powerful instrument in language learning.

\section{THETHEORETICAL BACKGROUND}

Information and communication technologies (ICT) can be a valuable tool supporting English language learning, also within formal teaching practice. The ongoing development of ICT is now a part of our personal lives, and is gradually gaining its considerable place in the educational curriculum [11]. Almost ten years ago today, Pegrum [12, p. 5] said that "technology and education have a tightly intertwined future" and his prediction has turned out to be correct.

Heift and Chapelle [13] claim that since the 1960s, the thought of using technology for learning has been in consideration. The focus was initially on CALL (Computer Assisted Language Learning) methods, but now we have to move on, and target our attention to MALL with answering the questions on how and to what extent new learning technologies affect successful learning outcomes.

Mobile devices such as smartphones and tablets are now more easily available than ever before. This fact corresponds with another trend - an increase in the amount of applications, which means that students can also learn outside of the formal classroom. This results in increased motivation and higher engagement in the learning process [14].

Although EFL learners are able to use language learning applications independently, teachers' roles are still essential in guiding the students as well as evaluating and suggesting appropriate applications to them. Language teachers still need to prepare for the lesson, using the applications as a helpful tool in leading the education process [15].

The students' option to use technology for accessing the content of learning English both inside and outside of the formal classroom opens up a new way of learning a language. It 
is obvious that using technology through word processing programs, bilingual dictionaries, and the Internet can help learners in their learning [14].

Jewell [16] maintains that a learner-centred pedagogy that makes the learner more active in their learning process has its place in learning through technology. The use of technology in education comes with many benefits, but naturally it has its drawbacks, too. It is necessary to align technology with the concept of language learning, but there is also need to set some limitations for technology so that it does not "swallow up" the whole education process, but serves as a powerful aid [14]. This means that in everyday learning, education is not determined by technology and vice versa. As stated by O'loughlin, Barton and Ngo [17, p. 301], there are evident benefits of using mobile technology in the class such as technological flexibility and content management. These offer a range of possibilities for various levels of teaching engagement.

Carenzio, Triacca and Rivoltella[18]published a paper on enhancing the learning process with tablet PCs with teachers of English. The teachers perceived tablets as a valuable tool for education and as a useful gadget for increasing and promoting collaborative learning.

According to Palloff and Pratt[19, p. 61]“"[m]obile technology is not a fad or trend of technology that will eventually go away. Mobile learning is the harbinger of the future of learning technology, it has the potential to change learning and teaching as we have known it. The use of this technology can empower students to become true informal learners that carry the knowledge through a lifetime of practice".

The course of mobile language learning at a personal level depends mainly on the individual user and the context of learning. Therefore, to boost the efficiency of learning with mobile devices, it would be helpful to provide instructions and guidance for the learners $[4, \mathrm{p}$. 10].

Quing[20] suggests the following ways to boost the strategies of mobile learning:

1. Personalized learning aimed to share all the learning materials with the students and to close the educational gap among them;

2. Systematic instructions, extra home assignments for practising the skills and language systems and an easy communication through mobile devices of the teachers and their students.

It is apparent that mobile devices are already creating a considerable impact on all spheres of human activity, including education. Therefore, it is important that educators and researchers devote serious attention to mobile technologies and carry out careful investigation intoits influence over language learning.

\section{RESEARCH METHODOLOGY}

\subsection{Research objectives}

The research aims were specified to examine:

- on which devices, where and how often EFL learners use mobile applications so as to develop their English skills;

- which skills and systems EFL learners primarily focus on when learning English through mobile applications; English.

- what types of mobile applications EFL learners use most frequently for learning

It should be also noted that three mobile devices were identified for the purposes of this study: smartphones, tablets, and smartwatches as they are portable, handheld, compact and lightweight. Some studies that deal with MALL also include other devices such as PDAs, netbooks, or even laptops. Even though these devices can be regarded as "mobile", they 
didnot seem to be suitable to be employed in this study. Furthermore, PDAs and netbooks can be evenconsidered as outdated.

\subsection{Research methods}

The selected method of data collection for the purpose of this study was a questionnaire. For this study, an electronic form of a questionnaire was selected. It was created in Google Docs Forms, containing 10 items. Altogether 47 responses were collected, but it was necessary to remove 9inappropriate answers. Thus, 38 responses were then left for the questionnaire evaluation.

\subsection{Research participants}

38 research participants included $28(73.7 \%)$ female respondents and $10(26.3 \%)$ male EFL respondents. 30 participants were students; 7 (18.4\%) studying at high school; 14 $(36.8 \%)$ at a university, 1 st degree; $8(21.1 \%)$ at a university, 2 nd degree; $1(2.6 \%)$ at a university, 3rd degree. Eight of the survey respondents $(21.1 \%)$ stated that they did not study anymore. The participants' age ranged from 16 to 32, with the average age being 22.3.

In addition, we wanted to know the respondents' level of English. We included all levels of English according to the CEFR (Common European Framework of Reference for Languages) into the questionnaire. 12 participants (31.6\%) stated that their English level was at the B1 CEFR level; 14 participants $(36.8 \%)$ were at the B2 CEFR level; 11 participants $(28.9 \%)$ were at the C1 CEFR level; and 1 participant (2.6\%) was at the C2 CEFR level.

\section{THE RESULTS AND DISCUSSION}

Question no. 1: I learn English more often by means of mobile applications than by traditional forms of studying (e.g. books, language courses, etc.).

This question was designed to determine whether the EFL learners devote their studying time more to the traditional forms of studying or to learning through mobile applications. The results show that 16 participants (42\%) learn English more often by means of mobile applications. 14 respondents (37\%) stated that they disagree with this statement, assuming that they prefer learning English by other forms of studying. 8 participants (21\%) responded $I$ don't know for this question.

\section{I learn English more often by means of mobile applications than by traditional forms of studying}

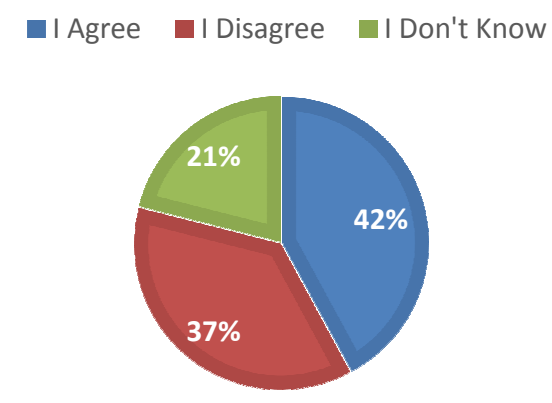

Figure 1.Ways of learning English 
The results for question no. 1, therefore, seem to indicate that MALL may be becoming more and more popular with EFL learners.

\section{Question no. 2: I use these mobile applications for learning English.}

The results of question no. 2 were divided into two application categories: dictionary applications and non-dictionary applications. The first group represents all types of dictionary applications listed in the responses such as Merriam Webster Dictionary, Oxford Dictionary of English, Google Translate, DIC-o Slovak-English Dictionary, together representing 68\%. Only three non-dictionary mobile applications were detected in the questionnaire responses, namely Duolingo, English Grammar Test, and Memrise. These applications represent 32\% of the mobile applications used for learning English.

\section{I use these mobile applications for learning English}

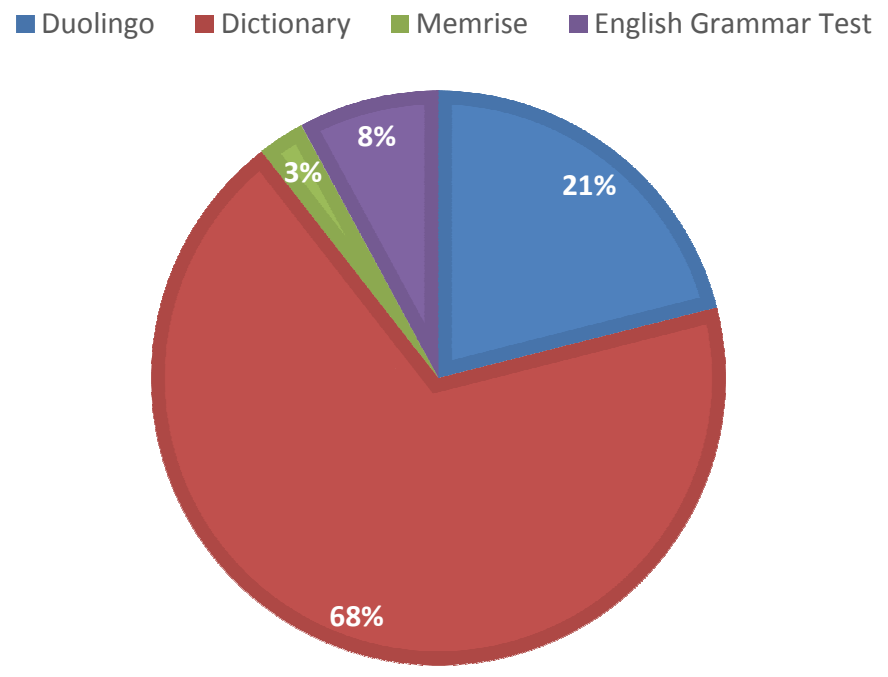

Figure 2. Mobile applications used for learning English

All of the applications were downloaded on Google Play Store and tested on an Android smartphone. The dictionary applications (Merriam Webster Dictionary, Oxford Dictionary of English, Google Translate, DIC-o Slovak-English Dictionary) are available for free at the store, some with the additional option to pay a yearly fee for a premium version. Each of them offers a variety of options and functions and it is solely up to the user which dictionary app they prefer to use.

Question no. 3. I use mobile applications for learning English (frequency).

The frequency of using mobile applications for learning English was limited into six answers: Every Day (16\%), Every Other Day (21\%), Once a Week (18\%), Once in Two Weeks (11\%), Once a Month (5\%), and Occasionally (29\%). Thus, the answers exhibit a diverse range in terms of how frequently mobile applications are used for learning English. 


\section{I use mobile applications for learning English}

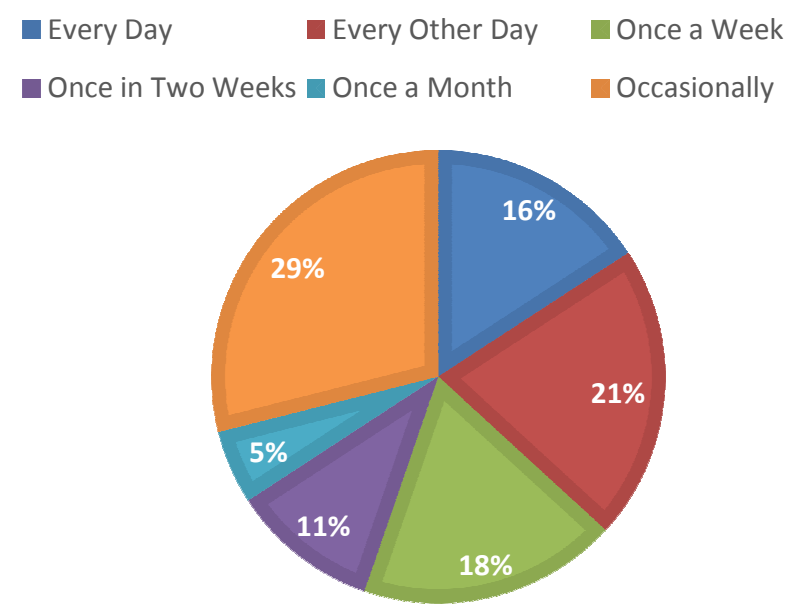

Figure 3. Frequency of using mobile applications for learning English

\section{Question no. 4. I usually use mobile applications for learning English on this operating system.}

The application market content is growing steadily as well as markets for various smart devices. The research data show that an overwhelming number of learners (26) use smart devices with Android operating system (68\%), while 11 respondents use Apple products with iOS (29\%) and only 1 respondent uses Windows-powered smart device (3\%). It seems that Android devices may be more popular because of their better affordability and more convenient selection of applications on the market.

\section{I usually use mobile applications for learning English on this operating system}

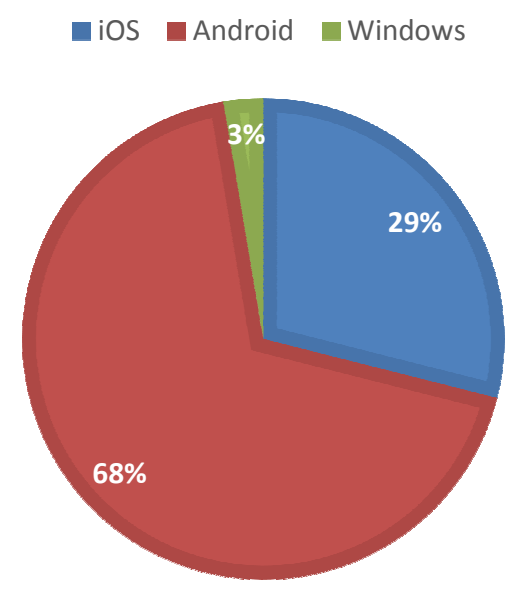

Figure 4. Operating systems used for mobile English learning

Question no. 5. Order the types of devices on which you use mobile applications for learning English.

The respondents ordered the mobile devices they use from 1(the device they use the most often) to 3 (the device they use the least often). The presented results show that the smartphone is the device which is used the most for MALL practicing (32 out of 38 
respondents selected their preference as value 1), followed by the tablet (value 2 selected $32 / 38$ respondents) and the least used mobile device is the smartwatch (value 3 selected 31/38 respondents).

\section{Q: 5 Order the types of devices on which you use mobile applications for learning English}

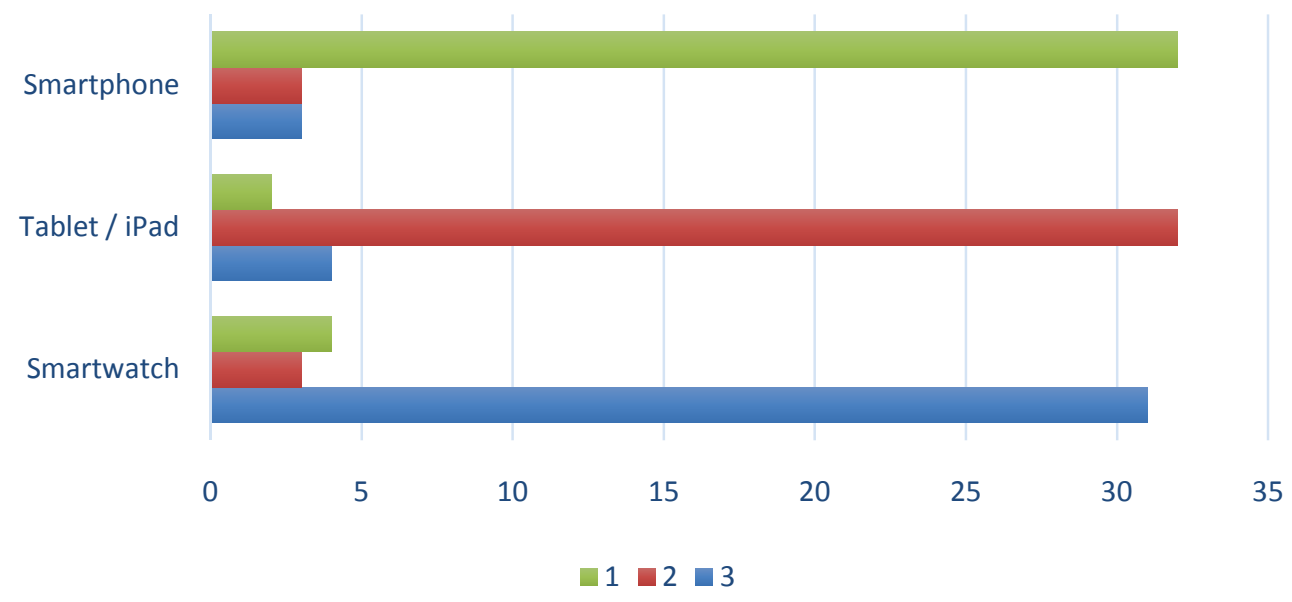

Figure 5. Types of devices used for mobile English learning

\section{Question no. 6. Order the places where you use mobile applications for learning English most often.}

The respondents were able to choose from three different options. The participants were asked to order the places where they use mobile applications for learning English from 1- the place where they use the applications the most to 3 - the place where they use the applications the least. The results show that EFL learners use language-learning applications most frequently at home (20 out of 38 respondents selected value 1), followed by studying at school/at work (21/38 respondents selected value 2$)$, which was followed by the commuting option (23/38 respondents selected value 3$)$.

\section{Q: 6 Order the places where you use mobile applications for learning English most often}

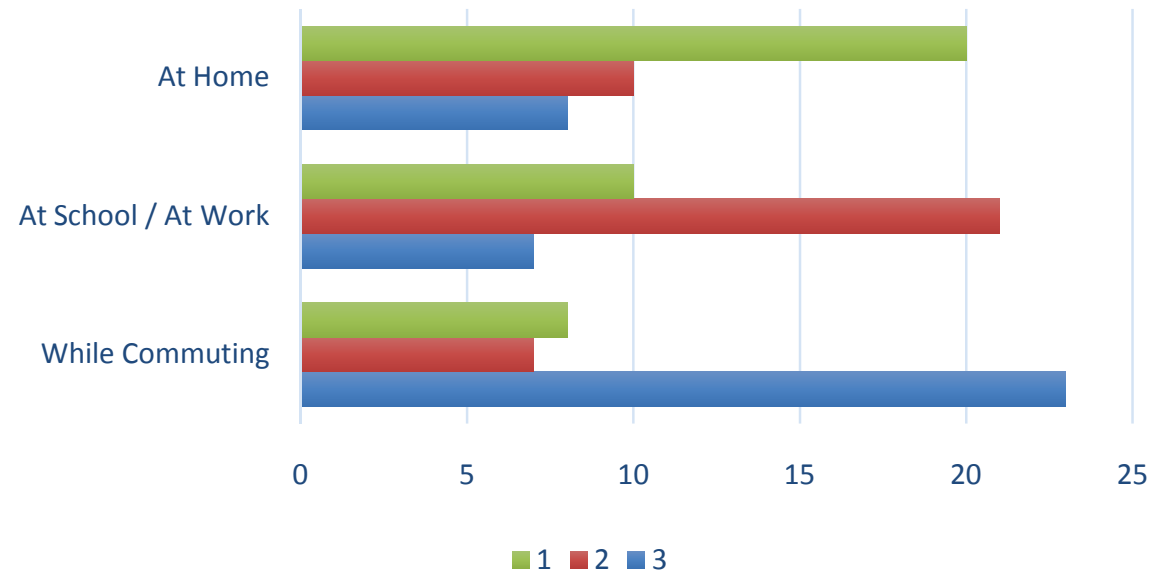

Figure 6.1 Places used for mobile English learning 
Question no. 7. Order the English skills you focus on while learning English by means of mobile applications.

Applications available on the market may be focused primarily on only one of the four skills, or they can include the possibility to work on more skills (listening, reading, writing, speaking).

The respondents were required to order the English skills they focus on while learning English by using mobile applications from 1- the highest amount of time spent on learning this particular skill to 4 - the lowest amount of time spent on learning this particular skill. The results demonstrate that the EFL learners primarily focus on listening (13 out of 38 respondents selected value 1$)$, followed by reading (13/38 respondents selected value 2$)$, writing (12/38 respondents selected value 3$)$, and speaking (14/38 respondents selected value 4).

\section{Q: 7 Order the English skills you focus on while learning English by means of mobile applications}

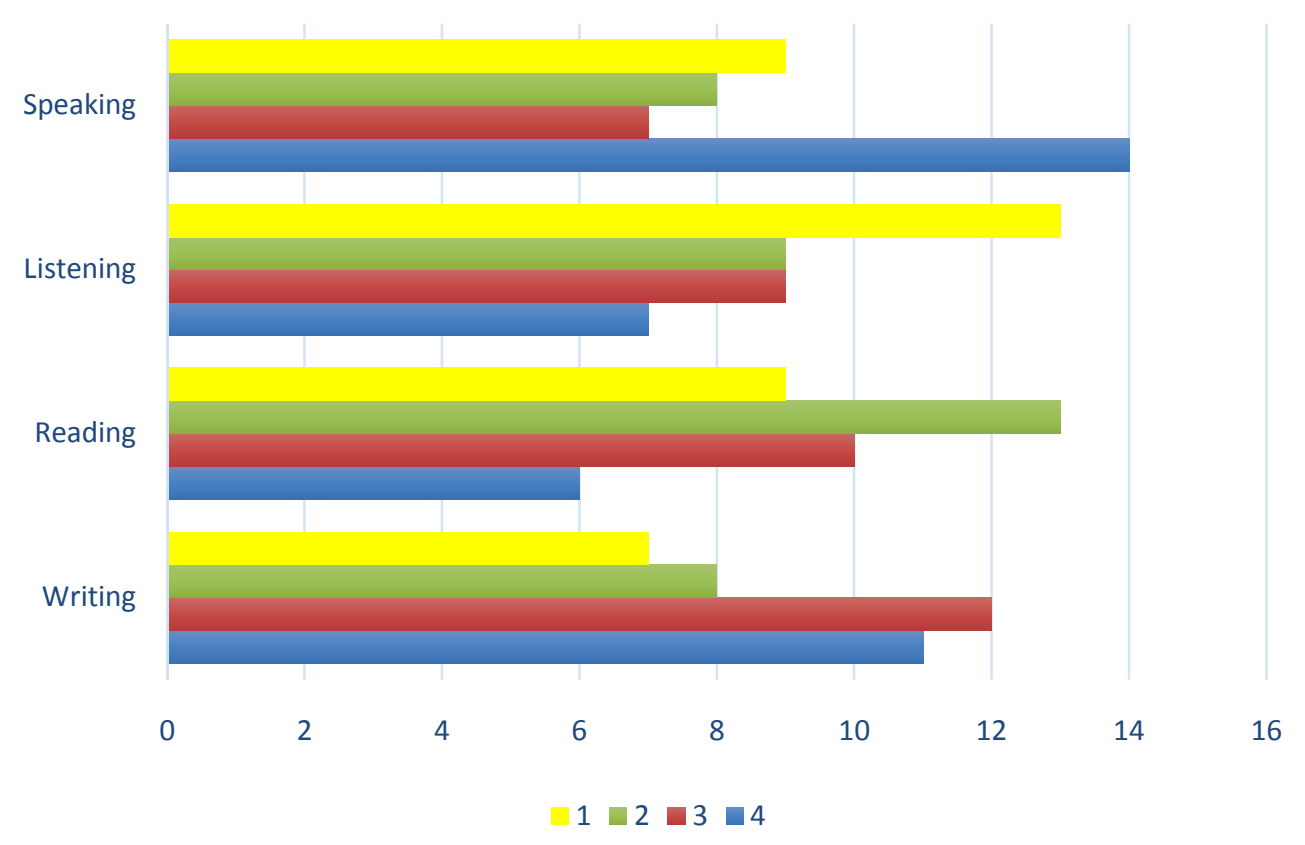

Figure 7.2 English skills preference in mobile learning

\footnotetext{
Question no. 8. Order the systems of English you primarily focus on while learning English by means of mobile applications.

This question was aimed to investigate the system that EFL learners focus on most while studying English by using mobile applications. The participants had to order the systems from 1- the highest amount of time spent on learning this particular system to 3 - the lowest amount of time spent on learning this particular system. Grammatical, Lexical, and Phonological systems were employed for the purposes of this research.

The results indicate that it is the vocabulary system which is the primary object of interest for EFL learners (24 out of 38 respondents selected value 1). The second most important system was grammar (16/38 respondents selected value 2$)$, and the third one was pronunciation (20/38 respondents selected value 3$)$.
} 


\section{Q: 8 Order the systems of English you primarily focus on while learning English by means of mobile applications}

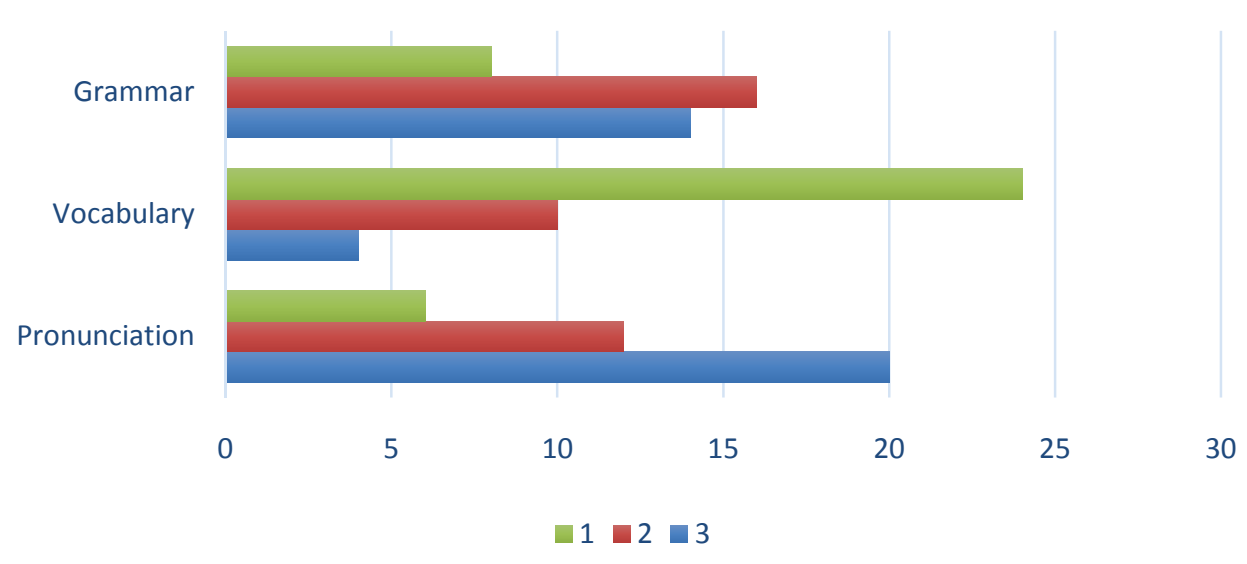

Figure 3. English systems preference in mobile learning

Question no. 9. Using mobile applications for learning English is an effective method of developing language skills.

This question revealed that a positive attitude (84\%) towards the effectiveness of learning English through mobile applications prevails over both negative and neutral opinions (16\%), which means that EFL learners regard them as effective ways of developing language skills.

\section{Q: 9 Using mobile applications for learning English is an effective method of developing language skills}

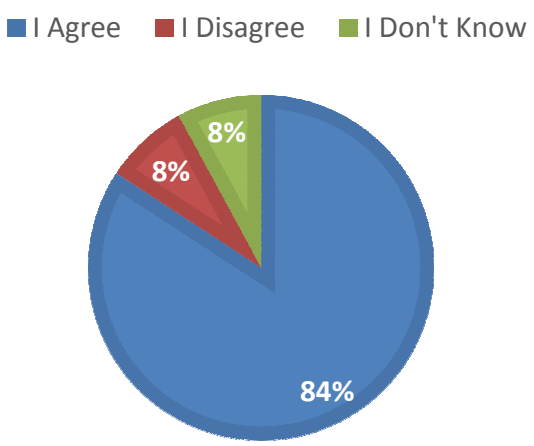

Figure 4. Effectiveness of mobile English learning

Question no. 10. Mobile technologies for the purposes of teaching and learning English should be used at English lessons at school.

Mobile technologies definitely have their place in the future of teaching and learning languages. The results were as follows: $28(74 \%)$ of the respondents think that mobile technologies have their place at English lessons at school, and only 4 respondents $(10 \%)$ disagree with this statement; $6(16 \%)$ respondents answered that they do not know. 


\section{Q: 10 Mobile technologies for the purposes of learning and teaching English should be used at English lessons at school}

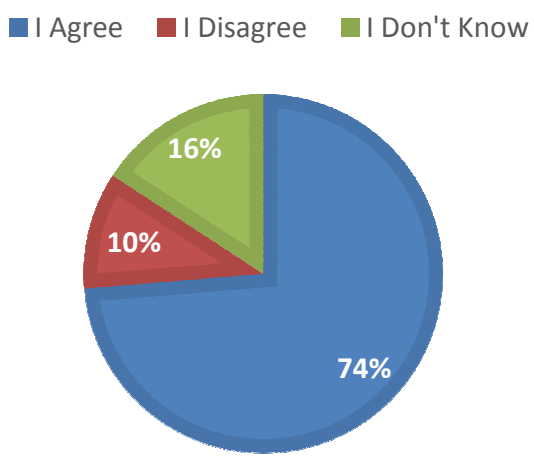

Figure 10. Use of mobile technologies at English school lessons

\section{CONCLUSIONS AND PROSPECTS FOR FURTHER RESEARCH}

The study illustrates that the most preferred device for MALL is the smartphone, followed by the tablet PC, and smartwatch. Young people nowadays would scarcely imagine that the purpose of using mobile phones is just making phone calls. The smartphone now offers countless possibilities for its use; from its basic functions like making calls or writing SMS, to accessing the Internet, listening to music, watching videos, taking photos, recording videos, playing games, working, using it as a navigation system or as a learning instrument, etc. Mobility and versatility of smartphones make it an attractive and practical option for MALL.

Tablet PCs may be sometimes more «powerful" and have the advantage of a bigger touchscreen, for example, but it also means that they are not as easy to carry around as smartphones or smartwatches.

Next, this article attempted to find out the most preferred place for studying English through MALL. The results show that EFL learners prefer learning English through mobile applications at home. This enables the learner to immerse in the language more as it is a personalized learning environment which is beneficial to the learners. This offers the possibility of managing their study time which also causes less tension in the learning process [21].

The frequency of using mobile applications for learning English was also explored. The collected data showed diverse use of mobile applications for learning English. It is assumed that this result may be influenced by the fact that learning English through MALL is not that widespread, and the situation seems to be similar in other countries of the world.

The purpose of the second aim was to find out which skills and systems the EFL learners mainly focus on when practicing MALL. The results indicate that the learners primarily concentrate on developing their listening skills, followed by reading, writing, and speaking skills, respectively. Listening is the first of the four skills and supposedly the most important one to master. It can be perceived as one of the main pillars when learning a language. There are quite many possibilities to improve listening skills through mobile language-learning applications such as listening to podcasts or practicing on in-app exercises that are read out loud by a native speaker. As far as non-language-learning applications are concerned, EFL learners can enhance their listening skills by watching videos in English, 
listening to a foreign web radio, watching live streams, films or series in multimedia applications, or communicating with their peers in English through social media applications.

When it comes to language systems, the EFL learners mainly concentrate their attention on improving their vocabulary. This finding corresponds with the fact that most learners use dictionary applications for their improvement. Many students would probably agree that vocabulary is the most important system to master. Speakers are more likely to be understood when they use incorrect grammar, but they are less likely to succeed in communicating a message when they use inappropriate vocabulary.

Finally, this paper investigated the types of mobile applications that are used for English learning. According to the collected data, the learners primarily use dictionary applications such as Google Translate, Merriam Webster Dictionary, Oxford Dictionary of English and DIC-o Slovak-English Dictionary, followed by full-purpose language-learning applications Duolingo, Memrise, and English Grammar Test. The selection of the appropriate application is solely in the hands of the learner, and reflects their study needs and goals.

What this study found out is that the attitude towards technologies in education is very positive with EFL learners, and hence the mobile technologies implication sought to be the subject of further examination by teachers, researchers, and academics worldwide.

It should be also noted that future research conducted on a larger sample of participants would definitely be of contemporary relevance and considerable importance to both teachers and learners as mobile devices seem to occupy an influential role in learning languages. Furthermore, employing other research methods such as observation or testing would cast more light on this matter.

Learning English through mobile applications is an interesting and innovative method in the technological world of today. The topic of modernization in education is being discussed worldwide, including Slovakia. However, there are still many shortcomings that need to be examined when it comes to using mobile devices for the purposes of language learning in Slovakia.

\section{REFERENCES}

[1] Marcial, D. (2017). ICT Social and Ethical Competency among Teacher Educators in the Philippines. Information Technologies and Learning Tools, 57(1), 96-103. Retrieved from https://journal.iitta.gov.ua/index.php/itlt/article/view/1533/1137

[2] Vaskivska, H., Kosianchuk, S., \&Skyba, H. (2017). Didactic Possibilities of Information and Communication Technologies in the Process of Development of Educational Environment in Upper Secondary School. Information Technologies and Learning Tools, 60(4), 17-27. Retrieved from https://journal.iitta.gov.ua/index.php/itlt/article/view/1790/1228

[3] Bugaychuk, K. (2012). Mobile Learning: Essence and Models of Introduction in Educational Process of Higher Educational Establishments Mia of Ukraine. Information Technologies and Learning Tools, 27(1). Retrieved from https://journal.iitta.gov.ua/index.php/itlt/article/view/619

[4] Shyshkanova, G., Zaytseva, T., \&Frydman, O. (2017). Mobile Technologies Make Education a part of Everyday Life. Information and Learning Science, 118, 570-582. https://doi.org/10.1108/ILS-03-20170019

[5] Kim, S. (2014). A Study on Adoption Factors of Korean Smartphone Users: A Focus on TAM (Technology Acceptance Model) and UTAUT (Unified Theory of Acceptance and Use of Technology). Advance Science and Technology Letters, 57, 27-30. http://dx.doi.org/10.14257/astl.2014.57.07

[6] Godwin-Jones, R. (2017). Smartphones and Language Learning. Language Learning \& Technology, 21(2), 3-17. Retrieved from: http://www.lltjournal.org/item/2995

[7] Vavoula, G., \&Sharples, M. (2002). KLeOS: A Personal, Nobile, Knowledge and Learning Organisation System. In Milrad, M., Hoppe, U and Kinshuk (Eds.) Proceedings of the IEEE International Workshop on Mobile and Wireless Technologies in Education, Sweden, pp. 152-156.

[8] Kukulska-Hulme, A. (2009). Will Mobile learning change language learning? The Journal of the European Association for Computer Assisted Language Learning, ReCALL, 21(2), 157-165. https://doi.org/10.1017/S0958344009000202 
[9] Kukulska-Hulme, A. (2013). Mobile-assisted Language Learning. In C. Chapelle (Ed.) The encyclopaedia of Applied Linguistics, pp. 3701-3709. New York: Wiley.

[10] O'malley, C. et al. (2003). Guidelines for Learning/Teaching/Tutoring in a Mobile Environment. Public deliverable from the MOBILearn project (D.4.1).

[11] Khubyari, L. \&Narafshan, M. (2016). A study on the Impact of MALL (Mobile Assisted Language Learning) on EFL Learners' Reading Comprehension. International Journal of English Language Teaching, 4(2), 58-69. Retrieved from http://www.eajournals.org/wp-content/uploads/A-Study-on-theImpact-of-MALL-Mobile-Assisted-Language-Learning-on-EFL-learners----Reading-comprehension.pdf

[12] Pegrum, M. (2009). From Blogs to Bombs. Crawley: UWA Publishing.

[13] Heift, T. \&Chapelle, C.A. (2012). Language Learning through Technology. In S. Gass, and A. Mackey (Eds.) The Routledge Handbook of Second Language Acquisition, pp. 555-569. New York: Routledge.

[14] Alduwairej, M. (2014). Attitudes Towards the Use of Technology Among the College Students Who Study English as a Second Language (ESL). ETD Archive: Cleveland State University. Paper 824. 89 p.

[15] Kim, H., \& Kwon, Y. (2012). Exploring Smartphone Applications for Effective Bobile-Assisted Language Learning. Multimedia-Assisted Language Learning, 15(1), 31-57.

[16] Jewell, M. (2006). Real-World Contexts, Skills and Service Learning for Secondary School Language Learners. In E. Hanson-Smith and S. Rilling (Eds). Learning languages through technology. Alexandria, VA: TESOL

[17] O'loughlin, A., Barton, S., \& Ngo, L. (2013). Using Mobile Technology to Enhance Teaching. In Z. Berge and L. Muilenburg (Eds.) Handbook of Mobile Learning, pp. 293-306. New York: Routledge.

[18] Carenzio, A., Triacca, S., \&Rivoltella, P. (2014). Education Technologies and Teacher's Professional Development. The Project Motus (Monitorins Tablet utilization in School) Run by Cremit. REM Research on Education and Media, 6(1), 25-38. Retrieved from http://ojs.pensamultimedia.it/index.php/rem_en/article/view/1075/1045

[19] Palloff, R. \& Pratt, K. (2013). Lessons from the Virtual Classroom: the Realities of Online Teaching. Oxford: John Wiley \& Sons.

[20] Qing, X. (2016). A Brief Study on English Autonomous Learning Ability Based on Mobile Learning in EFL Curriculum. Canadian Social Science, 12(11), 114-118.

[21] Markiewicz, J. \& Petersen, S. (2009). PALLAS: Personalised Language Learning on Mobile Devices.Fifth IEEE International Conference on Wireless, Mobile, and Ubiquitous Technology in Education, pp. 52-59. ISSN 0-7695-3108-3/08

Text of the article was accepted by Editorial Team 25.05.2018

\title{
РОЗВИТОК МОВЛЕННСВИХ НАВИЧОК У ПРОЦЕСІ НАВЧАННЯ АНГЛІЙСЬКОЇ МОВИ ЗАСОБАМИ МОБІЛЬНИХ ДОДАТКІВ
}

\author{
Міхаела Фучекова \\ студент бакалавріата \\ Жилінський університет, м.Жиліна, Словаччина \\ fucekova.m@gmail.com \\ Растіслав Метрук \\ доктор філософії, старший викладач \\ Жилінський університет, м.Жиліна, Словаччина \\ rastislav.metruk@gmail.com
}

\begin{abstract}
Анотація. Сучасні технології набувають популярності і впливають на кожну сферу людської діяльності, включаючи світ. Таким чином, ІКТ (інформаційні-комунікаційні технології) стали невід'ємною частиною навчального процесу. У цій статті розглядаються можливості вивчення англійської мови за допомогою мобільних додатків. 3 метою проведення дослідження було вибрано три мобільні пристрої, а саме: смартфон, планшет та смарт-годинник. Загалом анкету заповнилиз8 учасників зі Словаччини. Запитання, які були запропоновані в анкеті,стосувалися типів мобільних пристроїв: де саме та як часто вони використовуються. Крім того, в цьому дослідженні було визначено, які навички (слухання, читання, говоріння, письма) та які види мобільних додатків найчастіше застосовують користувачі. Результати досліджень вказують на те, що найбільш популярним пристроєм $\epsilon$ смартфон. Найчастіше мобільні додатки учні використовують вдома, але дослідження показало різний діапазон частоти їх застосування в процесі вивчення англійської мови. Що
\end{abstract}


стосується мовленнєвих навичок, то можна зробити висновок, що учні переважно зосереджуються на слуханні, а вже потім на читанні, письмі та розмові. Вивчаючи перевагу мовних систем, за результатами дослідження треба зазначити, що студенти перш за все концентруються на лексиці, потім граматиці та вимові. Крім цього було встановлено, що найчастіше використовуються додатки із словниками. Таким чином, можна зробити висновок, що мобільні додатки є потужним та популярним освітнім інструментом, через це цьому питанню необхідно приділити більш уваги викладачам, науковцям та дослідникам світової освітньої спільноти. Крім того, вважаємо, що подальше дослідження цього питання є необхідним і буде корисним як для вчителів-лінгвістів, так і для студентів, які вивчають англійську мову.

Ключові слова: мобільні додатки; вивчення мови із застосуванням мобільного телефону;студенти, які вивчають англійську мову як іноземну; мовленнєві навички; мовні системи.

\title{
РАЗВИТИЕ РЕЧЕВЫХ НАВЫКОВ В ПРОЦЕССЕ ОБУЧЕНИЯ АНГЛИЙСКОГО ЯЗЫКА СРЕДСТВАМИ МОБИЛЬНЫХ ПРИЛОЖЕНИЙ
}

\author{
Михаэла Фучекова \\ студент бакалавриата \\ Жилинский университет, г. Жилина, Словакия \\ fucekova.m@gmail.com \\ Растислав Метрук \\ доктор философии, старший преподаватель \\ Жилинский университет, г. Жилина, Словакия \\ rastislav.metruk@gmail.com
}

\begin{abstract}
Аннотация. Современные технологи приобретают популярность и влияют на каждую сферу человеческой деятельности, включая образование. Таким образом, ИКТ (информационно-коммуникационные технологии) стали неотъемлемой частью ученого процесса. В этой статье рассматриваются возможности изучения английского языка с помощью мобильных приложений. С целью проведения исследования было выбрано три мобильные устройства, а именно смартфон, планшет и смарт-часы. В общем, анкету заполнили 38 участников из Словакии. Вопросы, которые были предложены в анкете, касались типов мобильных устройств, где именно и как часто они используются. Кроме того, в этом исследовании было определено, какие навыки (слушание, чтение, говорение, письмо) и виды мобильных приложений больше всего применяют пользователи. Результаты исследований указывают на то, что наиболее популярным устройством является смартфон. Чаще всего мобильные приложения ученики используют дома, но исследование показало разный диапазон частоты их применения в процессе изучения английского языка. Что касается речевых навыков, то можно сделать вывод, что учащиеся в основном сосредотачиваются на слушании, а уже потом на чтении, письме и разговоре. Изучая предпочтение языковых систем, по результатам исследования можно отметить, что студенты прежде всего концентрируются на лексике, затем грамматике и произношении. Кроме этого было установлено, что чаще всего используются приложения со словарями. Таким образом, можно сделать вывод, что мобильные приложения являются мощным и популярным образовательным инструментом, поэтому этому вопросу не обходимо уделить больше внимания преподавателям, научным работникам и исследователям мирового образовательного сообщества. Кроме того, считаем, что дальнейшее исследование этого вопроса необходимо и будет полезным, как для учителей лингвистов, так и для студентов, изучающих английский язык.
\end{abstract}

Ключевые слова: мобильные приложения; изучение языка с применением мобильного телефона; студенты, изучающие английский язик как иностранный; речевые навыки; языковые системы.

\section{(cc) BY-NC-SA}

This work is licensed under Creative Commons Attribution-NonCommercial-ShareAlike 4.0 International License. 